\title{
Miscarriage Definitions, Causes and Management: Review of Literature
}

\author{
Ibrahim A. Abdelazim ${ }^{1 *}$,Mohannad AbuFaza ${ }^{2}$, Prashant Purohit ${ }^{3}$, Rania H. Farag ${ }^{4}$ \\ ${ }^{l}$ Department of Obstetrics and Gynecology, Ahmadi Hospital, Kuwait and Ain Shams University, Egypt \\ ${ }^{2}$ Department of Obstetrics and Gynecology, Ahmadi Hospital, Kuwait \\ ${ }^{3}$ Department of Reproductive Medicine and Assisted Conception, Kings College Hospital, London, UK \\ ${ }^{4}$ Department of Obstetrics and Gynecology, Dar Alshifa Hospital, Kuwait
}

*Corresponding Author: Ibrahim A. Abdelazim, Professor of Obstetrics and Gynecology, Ain Shams University, Egypt and Consultant at Ahmadi Hospital, Kuwait Oil Company (KOC), Kuwait, Email: dr.ibrahimanwar@gmail.com

\begin{abstract}
The ESHRE defined recurrent miscarriage (RM) as $\geq 3$ consecutive pregnancy losses before 22 weeks`gestation. Five to fifteen percent of RM women have significantly elevated anti-phospholipid antibodies, and $85 \%$ of the RM couples had elevated levels of sperm DNA damage.

Endometrial stromal cells from women with $R M$ are more receptive (super receptivity) for low-quality embryos. The risk of sporadic and/or RM increased in women with positive thyroperoxidase antibodies (TPO$A b$ ), and the risk of miscarriage doubled in women with TSH >2.5 mIU/L in the first trimester.

A systematic review concluded that the prevalence of all uterine malformations was $15.4 \%$ among $R M$ women. Women with body mass index $\geq 25 \mathrm{~kg} / \mathrm{m}^{2}$ have increased risk of miscarriage compared to women with $B M I<25 \mathrm{~kg} / \mathrm{m}^{2}$. IVF with prenatal genetic testing suggested as treatment for RM due to chromosomal abnormalities. The majority of women (65-85\%) with uterine malformations as bicornuate or septate uterus have successful pregnancy after metroplasty, and the hysteroscopic metroplasty should be done only for women with septate uteri, after failed previous IVF-ET trials. Empirical progesterone may beneficial for women with $\geq 3$ consecutive miscarriages immediately preceding their current pregnancy. Combination of lower molecular weight heparin, and aspirin is superior to aspirin alone in the treatment of RM due to antiphospholipid syndrome.
\end{abstract}

Keywords: Miscarriage, definitions, causes, management

\section{DEFINITIONS}

Biochemical pregnancy loss or miscarriage is the pregnancy loss, which occurs after positive urinary or serum human chorionic gonadotropin (hCG), but before ultrasound or histological detection of pregnancy $(<6 \text { weeks })^{[1]}$.

Clinical pregnancy loss or miscarriage is the pregnancy loss, which occurs after ultrasound detection of intrauterine gestational sac, and confirmed by histological evidence of products of conception after the miscarriage ${ }^{[1]}$. Clinical miscarriages divided to; early clinical pregnancy losses ( $<12$ weeks), and late clinical pregnancy losses (between 12-21 weeks). The ESHRE (European Society of Human Reproduction, and Embryology) defined $\mathrm{RM}$ as $\geq 3$ consecutive pregnancy losses before 22 weeks ${ }^{[2]}$.

ARC Journal of Gynecology and Obstetrics

\section{EPIDEMIOLOGY OF MiscARRIAGE}

The use of sensitive, and accurate urinary hCG assays in the diagnosis of pregnancy demonstrated that only one-third of conceptions progress to a live birth. Thirty percent of human conceptions are lost before implantation, and another $30 \%$ after implantation but before the missed menses ( $3^{\text {rd }}$ or $4^{\text {th }}$ week), and both termed as preclinical losses ${ }^{[3]}$. Figure 1

The incidence of early clinical miscarriage is about $10-15 \%$. The incidence of late miscarriage is about $4 \%{ }^{[4]}$. Compared to sporadic miscarriage the incidence of $\mathrm{RM}$ is $0.8-1.4 \%$ if only clinical pregnancy included, and $2-3 \%$ if biochemical pregnancy included ${ }^{[4]}$. Maternal age, and number of previous miscarriages are two independent risk factors for a further 
miscarriage ${ }^{[5]}$. The incidence of early miscarriage significantly increased with advanced maternal age, from $10-15 \%$ in women aged 20 to 24 years to $51 \%$ in women aged 40 to 44 years $^{[5]}$. The risk of miscarriage is much higher in women with previous losses. The risk of miscarriage after two consecutive losses is between $17-25 \%$, and the risk of miscarriage after three consecutive losses is between 25$46 \%{ }^{[2,5]}$.

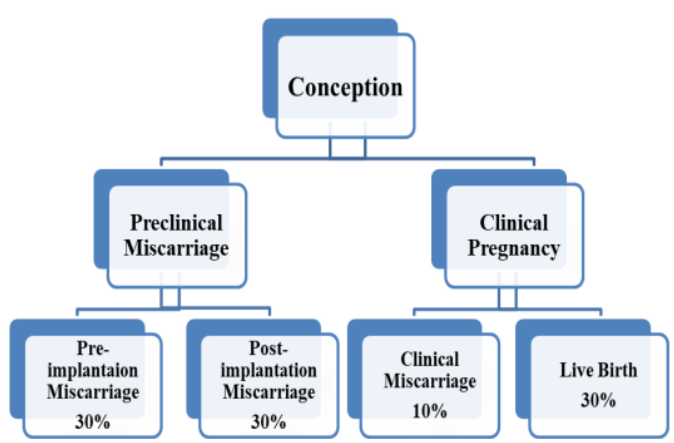

Figure1: The outcome of conception; $60 \%$ preclinical miscarriage, $10 \%$ clinical miscarriage, and $30 \%$ live birth

Advanced paternal age has also been identified as a risk factor for miscarriage. The risk of miscarriage is highest among couples where the woman is $\geq 35$ years of age, and the man $\geq 40$ years of age ${ }^{[6]}$.

\section{Table1. Causes of Miscarriage}

\section{Causes of Miscarriage or Pregnancy loss}

1. Chromosomal abnormalities; especially autosomal trisomy.

2. Immunological causes associated with failure of the mechanisms involved in the prevention of fetal rejection

3. Thrombophilias

A. Acquired Thrombophilia (APS).

B. Inherited Thrombophilia (factor V Leiden, prothrombin gene mutations, protein $\mathrm{C}$ and $\mathrm{S}$ deficiencies).

C. Methylenetetrahydrofolate reductase (MTHFR) gene mutation.

4. Endocrine causes

A. Polycystic ovary syndrome (PCOS), and insulin resistance(IR).

B. Luteal Phase defect (LPD).

C. Diabetes Mellitus (DM).

D. Thyroid Disorders; Subclinical hypothyroidism and thyroperoxidase antibodies (TPO-Ab).

5. Sperm DNA fragmentation.

6. Failure of embryo selection.

7. Uterine malformations.

8. hCG gene polymorphisms.

9. Lifestyle factors; Alcohol, coffee, smoking, advanced maternal age, and BMI $\geq 30 \mathrm{~kg} / \mathrm{m}^{2}$

10. Infections; Bacterial vaginosis as a risk factor for late miscarriage.

\subsection{Chromosomal Abnormalities}

Approximately $50-60 \%$ of early spontaneous miscarriages associated with aneuploidy, especially autosomal trisomy ${ }^{[15]}$. In couples with RM, increases with advancing maternal age ${ }^{[5]}$. However, parental karyotyping is not predictive for the subsequent pregnancy outcome, and routine karyotyping in RM is not recommended ${ }^{[16]}$. 
A large-controlled study showed that carrier couples with two miscarriages had the same chance of having a healthy child as non-carrier with the same number of miscarriages $(83 \%$ versus $84 \%$; respectively ${ }^{[16]}$. Cytogenetic analysis should be performed on products of conception of the third, and subsequent consecutive miscarriage(s), and parental peripheral blood karyotyping of both partners should be performed in couples with RM where testing of products of conception reports an unbalanced structural chromosomal abnormality ${ }^{[16]}$. [Evidence 3]

IVF/PGD suggested as faster method of conception than natural conception for translocation carriers couples or couples with chromosomal abnormalities, and RM ${ }^{[17]}$. [Evidence 4]

\subsection{Immunological causes}

Failure of the maternal immune recognition, and fetal antigen expression mechanisms involved in the fetal rejection, and subsequent RM. Although, there was no proof that the auto antibodies as; anti-phospholipid, anti-thyroid, and anti-nuclear have harmful or negative effect on pregnancy, those auto antibodies used as markers of immunological dysfunction or disruption in RM.

Studies reported increased levels of $\mathrm{T}$ helper cell cytokines or natural killer (NK) cells in the blood of women with euploid sporadic miscarriage, and in RM, but it is not clear whether the peripheral blood levels of those biomarkers reflects their levels at the fetomaternal interface or not ${ }^{[18]}$.

Although, the uterine NK cells play an important role in implantation, a systematic review concluded that the NK cells (both peripheral blood and uterine) are not predictive for the pregnancy outcome in RM ${ }^{[19]}$. The evidence of involvement of the immune system in miscarriage comes from genetic studies.

These studies showed that some genetic biomarkers of possible importance for immunologic dysfunction in pregnancy were found in women with RM. Those biomarkers are; maternal HLA class against male-specific antigens of male embryos, specific maternal NK cell receptor that associated with maternal NK cell recognition of the trophoblast ${ }^{[20]}$.

Prednisone, intravenous immunoglobulin (IVIG), and tumor necrosis factor $\alpha(\mathrm{TNF} \alpha)$ antagonists or granulocyte colony-stimulating factor (G-CSF) suggested as treatment for cases presented with RM due to immunologic dysfunction. The majority of those treatments have only tested in small RCTs, and the efficacy of them are controversial ${ }^{[21]}$. [Evidence 1++]

A meta-analysis showed that the use of IVIG improved the live birth rates in women with secondary RM compared to placebo, but the effect was not significant ${ }^{[22]}$. The use of unfractionated or LMWH in mice prevent complement activation, and pregnancy complications caused by IgG from women with APS ${ }^{[23]}$.

\subsection{Thrombophilias}

\section{a) Acquired Thrombophilia}

Antiphospholipid syndrome (APS) is the only proven thrombophilia associated with adverse pregnancy outcomes. Five to fifteen percent of RM women have elevated aPL-Abs compared to $2-5 \%$ of the controls ${ }^{[24]}$. APS refers to the association between antiphospholipid antibodies (lupus anticoagulant, anticardiolipin antibodies and anti-B2 glycoprotein-I antibodies), and adverse pregnancy outcome and/or vascular thrombosis. Adverse pregnancy outcomes include: 1) $\geq$ one unexplained fetal deaths of morphologically normal fetus $\geq 10^{\text {th }}$ weeks; 2 ) severe pre-eclampsia or placental insufficiency $<34$ weeks; 3) $\geq 3$ unexplained consecutive miscarriages <10th weeks ${ }^{[24-26]}$. The APS diagnosed by one of the adverse pregnancy outcome, and one laboratory criteria. Laboratory criteria include; positive Anti-cardiolipin (ACL) antibodies or high level of Anti- $\beta 2$ glycoproteinI antibodies on $\geq 2$ occasions (12 weeks apart) $[25,26]$.

\section{b) Inherited Thrombophilia}

Inherited thrombophilias includes; factor $\mathrm{V}$ Leiden, prothrombin gene mutations, protein $\mathrm{C}$ resistance, and protein $S$ deficiency ${ }^{[24]}$. Although, the previous studies found significant association between inherited thrombophilias, and still births after the $20^{\text {th }}$ weeks, rather than early pregnancy loss ${ }^{[24]}$.

A meta-analysis suggested that the association between inherited thrombophilias, and fetal loss varies according to the type of fetal loss, and type of thrombophilia. In this meta-analysis, factor V Leiden was associated with recurrent first-trimester fetal loss, recurrent fetal loss after 22 weeks, and non-recurrent fetal loss after 19 weeks. Activated protein $\mathrm{C}$ resistance was associated with recurrent first-trimester fetal 
loss. Prothrombin gene mutation was associated with recurrent first-trimester fetal loss, recurrent fetal loss before 25 weeks, and late nonrecurrent fetal loss. Protein S deficiency was associated with recurrent fetal loss and nonrecurrent fetal loss after 22 weeks ${ }^{[27]}$. [Evidence 2++]

Similarly, another meta-analysis reported that carriers of factor V Leiden or prothrombin gene mutation have double the risk of RM compared with controls ${ }^{[28]}$. [Evidence 2++]

\section{c) MTHFR Gene Mutation}

Methylenetetrahydrofolate reductase (MTHFR) is an enzyme that convert 5,10-MTHF (methyltetrahydrofolate) into 5-MTHF (circulating form of folate). MTHFR mutation associated with hyperhomocysteinemia, which considered a risk factor for neural tube defects, and RM ${ }^{[29]}$.

\subsection{Endocrine Causes}

a) Polycystic Ovary Syndrome (PCOS), and Insulin Resistance (IR)

PCO is common ultrasound finding seen in $40 \%$ of women with RM, studies showed that PCO is not predictive for the pregnancy outcome after spontaneous conception ${ }^{[30]}$. However, recent meta-analysis concluded that IR, and hyperinsulinaemia in PCOS women associated with increased susceptibility to RM ${ }^{[31]}$. [Evidence 1++]

\section{b) Luteal Phase Defect (LPD)}

$L P D$ associated with pregnancy loss, but the diagnosis of LPD using the histological, and the biochemical markers for endometrial dating are unreliable.

\section{c) Diabetes Mellitus (DM)}

Diabetic women who have high HbA1c levels in the first trimester are at risk of miscarriage, and fetal malformation ${ }^{[32]}$. HbAlc (glycosylated hemoglobin) gains an important role in diagnosis of $\mathrm{DM} / \mathrm{GDM}$ because oral glucose tolerance test (OGTT) is not a perfect test. In addition; fasting plasma glucose would miss women with glucose intolerance ${ }^{[33]}$.

\section{d) Thyroid Disorders}

Subclinical hypothyroidism with pregnancy associated with increased RM risk. A metaanalysis found that the risk of sporadic and/or RM increased in women with positive thyroperoxidase antibodies (TPO-Ab) ${ }^{[34]}$. In addition; the risk of miscarriage doubled in women with $\mathrm{TSH}>2.5 \mathrm{mIU} / \mathrm{L}$ in the first trimester ${ }^{[34]}$. [Evidence 1+]

Only a single prospective study has shown that the presence of thyroid antibodies in euthyroid women with a history of RM does not affect future pregnancy outcome ${ }^{[35]}$. [Evidence 3]

\subsection{Sperm DNA Fragmentation}

A meta-analysis found that the risk of miscarriage increased in couples where the male partner had elevated levels of sperm DNA damage compared to controls with no or low levels of sperm DNA damage ${ }^{[36]}$. In addition; the paternal role in RM suggested in another studies, which showed that $85 \%$ of the RM couples had high levels of double-stranded sperm DNA damage compared to $33 \%$ of the controls ${ }^{[37]}$.

\subsection{Failure of Embryo Selection}

The decidual endometrial stromal cells (ESCs) act as biosensor for embryonic signals, and able to select the embryos for implantation based on their qualities. The first study demonstrated the biosensor function of ESCs showed reduced production of the regulatory cytokines of implantation in response to poor quality or nonviable embryos ${ }^{[38]}$. These findings provided the first explanation to the hypothesis suggested by Quenby et al, that women with RM may allow embryos of poor quality to implant inappropriately ${ }^{[39]}$. In women with RM the endometrial selectivity to embryos of good quality is disrupted, and they allow low quality embryos to implant rather than lost as preclinical biochemical pregnancy ${ }^{[40]}$.

Moreover, ESCs of women with RM showed prolonged receptivity (super receptivity), with low selectivity for low quality embryos ${ }^{[40]}$. A recent study showed that the migration of ESCs from RM women was similar in the presence of low-quality or high quality embryos ${ }^{[41]}$.

\subsection{Uterine Malformations}

Uterine malformations associated with RM are; didelphic, bicornuate, arcuate, and septate uteri. A large systematic review showed by that, the prevalence of uterine malformations was $15.4 \%$ among RM women compared to $5.5 \%$ among controls ${ }^{[42]}$.

Kowalik et al, showed that the first trimester miscarriage significantly increased in women with septate uteri compared to controls, and they suggested a positive effect of septal resection on 
the pregnancy outcome ${ }^{[43]}$. The combination of hysteroscopy, and laparoscopy is the gold standard method for the diagnosis of the uterine malformations. The three dimensional ultrasound is more accurate than 2D ultrasound, and equal to MRI for the diagnosis of the uterine malformations ${ }^{[44]}$. Saline sonohysterography (SIS) is a non-invasive, cost-effective method with $95 \%$ accuracy in identifying the uterine malformations, and Reda et al, suggest that there is a good role of SIS in the workup for recurrent implantation failure (RIF) saving more invasive procedure for selected cases ${ }^{[45]}$. The two dimensional ultrasound can used as an initial screening tool for the diagnosis of uterine malformations, while, combined hysteroscopy, and laparoscopy, SIS, MRI, and 3D ultrasound can used as confirmatory tools ${ }^{[44]}$. [Evidence 3]

\section{8. hCG Gene Polymorphisms}

hCG is glycoprotein consist of $\alpha$ and $\beta$ subunits, secreted by syncytiotrophoblast to maintain the progesterone secretion from the corpus luteum in early pregnancy. Early miscarriage associated with low hCG levels in maternal blood. The low hCG levels in maternal blood may be due to; (1) impaired trophoblast growth caused by aneuploidy, thrombophilia or immune dysfunctions with low hCG production (external hCG treatment will not be beneficial), or (2) primary trophoblastic failure with subsequent inadequate $\mathrm{hCG}$ secretion from the trophoblast (treatable with hCG or progesterone therapy). The $\beta$ subunit of hCG is coded by 4 chorionic gonadotropin $\beta$ (CGB) genes, and the CGB5 and the CGB8 are the most active ${ }^{[46]}$. A polymorphisms in the promoter region of the CGB5 gene that enhance hCG- $\beta$ transcription suggested, because lower levels of both hCG, and hCG- $\beta$ mRNA found in the tissue from RM women ${ }^{[46]}$.

\subsection{Life Style Factors}

Alcohol increase the risk of miscarriage significantly, and the national Danish birth study, suggested that the risk increased in a dose related manner ${ }^{[47]}$. Another Danish study, demonstrated increase risk of miscarriage in women drinking $>7$ cups of coffee per day ${ }^{[48]}$, and a large prospective study could not demonstrate an association between smoking, and miscarriage ${ }^{[49]}$. A meta-analysis concluded that women with body mass index (BMI) $\geq 25$ $\mathrm{kg} / \mathrm{m}^{2}$ are at high risk of miscarriage compared to women with BMI $<25 \mathrm{~kg} / \mathrm{m}^{2}{ }^{[1]}$. A logistic analysis showed that the BMI $\geq 30 \mathrm{~kg} / \mathrm{m}^{2}$ was the most important risk factor after the advanced maternal age to predict another miscarriage ${ }^{[12]}$.

A systematic review investigating the relation between miscarriage, and obesity after spontaneous conception, showed significant association between obesity, and both sporadic and RM ${ }^{[50]}$.

\subsection{Infections}

The role of infection in RM is unclear, and for any infective agent to cause RM, it must be capable of persisting in the genital tract, and avoiding of detection. [Evidence 3]

Bacterial vaginosis is a risk factor for secondtrimester miscarriage, and preterm labor (PTL), and a RCT reported that treatment of bacterial vaginosis early in the second trimester significantly reduces the incidence of secondtrimester miscarriage, and PTL ${ }^{[51]}$.

\section{Management}

Psychological support, and counseling are crucial during the evaluation, and treatment of RM. The value of psychological support in improving pregnancy outcome has not been tested in RCTs. However, data from several non-randomized studies suggested that attendance at a dedicated early pregnancy clinic has a beneficial effect, through unknown mechanism ${ }^{[52,53]}$. [Evidence 2+]

Genetic counselling offers the couple a prognosis for the risk of future pregnancies with an unbalanced chromosome complement, and the opportunity for familial chromosome studies. Healthy life style, free from alcohol, tobacco, and undue stress may significantly improve the chances for successful pregnancy [54]. A Cochrane review concluded that the vitamin supplements before or during pregnancy did not prevent sporadic or $\mathrm{RM}^{[55]}$.

Genetic Anomalies: A Dutch study reported that couples with balanced translocations have a low risk $(0.8 \%)$ of pregnancies with an unbalanced karyotype surviving into the second trimester, and that their chance of having a healthy child is $83 \%{ }^{[16]}$. [Evidence 3]

A recent retrospective UK audit reported that balanced translocations were found in $1.9 \%$ of parents with RM, but only four unbalanced translocations were found after referral for prenatal diagnosis. The audit concluded that routine karyotyping of couples with RM cannot be justified ${ }^{[56]}$. [Evidence 3] 
IVF/PGD suggested as faster method of conception than natural conception for translocation carriers couples or couples with chromosomal abnormalities, and RM ${ }^{[55-59]}$. However, studies showed that the IVF/PGD treatment in women with unexplained RM does not improve live birth rates, and the live birth rate of women with unexplained RM who conceive naturally is significantly higher than currently achieved after PGD/IVF [60-61]. [Evidence 2+]

Anatomical Defects: The majority of women (65-85\%) with uterine malformations as septate uterus have successful pregnancy after metroplasty, and $59.5 \%$ of women with such anomalies have successful subsequent pregnancy without surgery. Although, there is no strong evidence to recommend metroplasty in women with septate uterus ${ }^{[43]}$. [Evidence 2+]

Hysteroscopic metroplasty should be done only for women with septate uteri, after failed previous IVF-ET trials ${ }^{[43]}$. In addition; the hysteroscopic metroplasty should done under laparoscopic guidance (combined hysterolaparoscopy) to avoid uterine perforation, and bowel injury during the procedure.

Although, the CERVO trial failed to find any benefit for the cervical cerclage in women with incompetent cervix ${ }^{[62]}$. Another study; concluded that the Shirodkar technique was more effective than McDonald technique in women with single pregnancy undergoing ultrasound-indicated cervical cerclage [63]. Cervical cerclage, and vaginal progesterone are equally effective in prevention of PTL in women with single pregnancy, and short cervix (less than $25 \mathrm{~mm}$ ) detected by mid-trimester trans-vaginal scan ${ }^{[64]}$. [Evidence 1+]

Infection: Treatment of asymptomatic bacterial vaginosis with clindamycin early in the second trimester significantly reduces the risks of late miscarriage, and PTL ${ }^{[51]}$.

Endocrine Disorders: Maternal endocrine disorders (diabetes, thyroid dysfunction) should treated before pregnancy. Hyperprolactinemia usually result in RM through impaired oocyte maturation, and LPD. Normalization of prolactin levels with dopamine agonist significantly improves the pregnancy outcomes ${ }^{[65]}$. Thyroid disorders should treated to achieve euthyroid status before pregnancy. A consensus is emerging that $\mathrm{TSH}$ values $>2.5 \mathrm{mIU} / \mathrm{L}$ are outside the normal range, and TSH should maintained at $<2.5 \mathrm{mU} / \mathrm{L}$ during pregnancy. Evidence suggests association between TPO$\mathrm{Ab}$, and $\mathrm{RM}$, and recommends Levothyroxine $50 \mu \mathrm{g}$ daily for women with TPO-Ab even in presence of normal TSH ${ }^{[66]}$. [Evidence 1+]

Progesterone: Progesterone is an immunemodulator, produces progesterone-induced blocking factors (PIBF) from the lymphocytes, and the PIBF inhibits cell-mediated cytotoxicity, and NK cells activity ${ }^{[67]}$. Progesterone therapy is ineffective for women with sporadic miscarriages, and may be beneficial for women with $\geq 3$ consecutive miscarriages immediately preceding their current pregnancy [68]. [Evidence 1+]

Metformin: No adequate published data or trials supporting the use metformin to decrease the risk spontaneous of miscarriages. Clinicians should advise women with IR to improve their insulin sensitivity through lifestyle modification or medical treatment before pregnancy to reduce the risk of spontaneous miscarriages. Nonrandomized studies showed that the use of metformin reduces IR in PCOS women, and may reduce the risk of miscarriages ${ }^{[69]}$. [Evidence 1++]

A meta-analysis of RCTs in women with PCOS, and infertility showed that metformin has no effect on the sporadic miscarriage risk when administered before pregnancy. However, there are no RCTs to assess the role of metformin RM women ${ }^{[70]}$. [Evidence 1++]

APS: Meta-analysis of RCTs reported that the only treatment that leads to a significant increase in the live birth rate among women with APS is aspirin plus unfractionated heparin or LMW heparin ${ }^{[71]}$.

This treatment combination significantly reduces the miscarriage rate by $54 \%$, and steroids associated with significant maternal, and fetal morbidity ${ }^{[72,73]}$. [Evidence $1+$ ]

Inherited Thrombophilia: There is insufficient evidence about the effect of heparin in prevention of first-trimester RM in women with inherited thrombophilia. One prospective RCT demonstrated that the live birth rate of women treated with enoxaparin after history of single miscarriage $>10$ weeks due to inherited thrombophilia was $86 \%$ compared with $29 \%$ in 
women treated with low-dose aspirin alone ${ }^{[74]}$. [Evidence 1+]

MTHFR Mutation: High-dose folic acid (5 $\mathrm{mg})$, and vitamin B12 (0.5 $\mathrm{mg})$ reduce the levels of homocysteine, and high-dose folic acid recommended for diabetic women with high BMI.

Immunotherapy: IVIG may work in women with RM through CD94 expression, and suppression of NK cell cytotoxicity ${ }^{[75]}$. Evidence does not support the use of intralipid in $\mathrm{RM}^{[76]}$.

A Cochrane systematic review has shown that the use of various forms of immunotherapy in women with unexplained RM provides no significant beneficial effect over placebo in preventing further miscarriage ${ }^{[21]}$. [Evidence $1++]$

Meta-analysis showed that the use IVIG increased the live birth rates in secondary RM, and the evidence for its use in primary RM was insufficient ${ }^{[77-78]}$.

Unexplained RM: Psychological support: Data from several non - randomized studies suggested that attendance at a dedicated early pregnancy clinic has a beneficial effect, through unknown mechanism ${ }^{[52,53]}$. [Evidence 2+]

Aspirin (75 mg daily): Aspirin improves the uterine perfusion, and useful in many undiagnosed implantation failure. Few RCT suggested clear benefit of aspirin in RM, while, the recent trials failed to support its role in unexplained $\mathrm{RM}^{[79]}$. [Evidence 1+]

Progesterone: Meta-analysis showed significant reduction in miscarriage rates with the use of progesterone ${ }^{[80]}$, and a large multicenter study (PROMISE, http://www.medscinet.net/promise) is currently going to assess the benefit of progesterone in unexplained RM. [Evidence 1+]

$h C G$ : Recent Cochrane review failed to find good evidence to support the use of hCG in prevention of miscarriage ${ }^{[81]}$. A multicenter placebo-controlled study in early pregnancy failed to show any benefit for hCG in pregnancy outcome $^{[82]}$. [Evidence 1+]

Steroids: Meta-analysis of RCTs reported that the only treatment that leads to significant increase in the live birth rate among women with APS is aspirin plus heparin, and steroids associated with significant maternal, and fetal morbidity ${ }^{[72,73]}$. [Evidence 1+]

Steroid therapy may be useful in some women with RM because of its effect on the endometrial growth factors ${ }^{[83]}$.

Immunoglobulins: IVIG administration for treatment of RM is not justified outside the context of research.

\section{SUMMARY}

APS is the only proven thrombophilia associated with adverse pregnancy outcomes, and aspirin plus heparin is the only treatment associated with reduction of miscarriage rate. The association between inherited thrombophilias, and fetal loss varies according to the type of fetal loss, and type of thrombophilia.

IR in PCOS associated with increased susceptibility to RM, and non-randomized trials showed that the use of metformin reduces IR in PCOS, and may reduce the risk of miscarriages.

The risk of miscarriage doubled in women with $\mathrm{TSH}>2.5 \mathrm{mIU} / \mathrm{L}$ in the first trimester, evidence suggests association between TPO-Ab, and RM. Although, the majority of women have successful pregnancy after metroplasty, there is no strong evidence to recommend metroplasty in women with septate uterus. Cervical cerclage, and vaginal progesterone are equally effective in prevention of PTL in women with single pregnancy, and short cervix $(<25 \mathrm{~mm})$ detected by TVS. Progesterone therapy may be beneficial for women with $\geq 3$ consecutive miscarriages immediately preceding their current pregnancy. The live birth rate of women with unexplained RM who conceive naturally is significantly higher than currently achieved after PGD/IVF. Evidence failed to show any benefit for hCG and/or aspirin in unexplained RM. Steroids, IVIG, TNF $\alpha$ antagonists and/or G-CSF efficacy in RM due to immunologic dysfunction are controversial.

\section{REFERENCES}

[1] Farquharson RG1, JauniauxE, Exalto N; ESHRE Special Interest Group for Early Pregnancy (SIGEP). Updated and revised nomenclaturefor description of early pregnancy events. Hum Reprod.2005; 20(11):300811.doi:10.1093/humrep/dei167.[Pub Med ]

[2] Jauniaux E, Farquharson RG, Christiansen OB, Exalto N. Evidence-based guidelines for the 
investigation and medical treatment of recurrent miscarriage. Hum Reprod. 2006; 21(9):22162222. doi: 10.1093/humrep/del150. [PubMed]

[3] Wang X, Chen C, Wang L, Chen D, Guang W, French J. Conception, early pregnancy loss, and time to clinical pregnancy: a population-based prospective study. Fertil Steril. 2003;79(3): 577-84. [PubMed]

[4] Macklon NS, Geraedts JP, Fauser BC. Conception to ongoing pregnancy: the 'blackbox' of early pregnancy loss. Hum Reprod Update. 2002; 8 (4):333-343. [PubMed]

[5] Nybo Anderson AM, Wohlfahrt J, Christens P, Olsen J, Melbye M. Maternal age and fetal loss: population based register linkage study. BMJ. 2000; 320 (7251):1708-12. [PubMed]

[6] De la Rochebrochard E, Thonneau P. Paternal age and maternal age are risk factors for miscarriage; results of a multicentre European study.HumReprod.2002;17(6):1649-56. [PubMed]

[7] Rasch V. Cigarette, alcohol, and caffeine consumption: risk factors for spontaneous abortion. Acta Obstet Gynecol Scand. 2003; 82 (2):182-8. [PubMed]

[8] Peck JD, Leviton A, Cowan LD. A review of the epidemiologic evidence concerning the reproductive health effects of caffeine consumption: a 2000-2009 update. Food Chem Toxicol.2010;48(10):254976.doi:10.1016/j.fct.2 010.06.019. [PubMed]

[9] Kesmodel U, Wisborg K, Olsen SF, Henriksen TB, Secher NJ. Moderate alcohol intake in pregnancy and the risk of spontaneous abortion. Alcohol Alcohol.2002; 37 (1):87-92. [PubMed]

[10] Lashen H, Fear K, Sturdee DW. Obesity is associated with increased risk of first trimester and recurrent miscarriage: matched casecontrol study. Hum Reprod. 2004; 19 (7):16446. doi: 10.1093/humrep/deh277. [PubMed]

[11] Metwally M, Ong KJ, Ledger WL, Li TC. Does high body mass index increase the risk of miscarriage after spontaneous and assisted conception? A metaanalysis of the evidence. Fertil Steril. 2008; 90(3):714-26. [PubMed]

[12] Metwally M, Saravelos SH, Ledger WL, Li TC. Body mass index and risk of miscarriage in women with recurrent miscarriage. Fertil Steril. 2010;94(1):2905.doi:10.1016/j.fertnstert.2009.0 3.021. [PubMed]

[13] Kurahashi H, Tsutsumi M, Nishiyama S, Kogo $\mathrm{H}$, Inagaki $\mathrm{H}$, Ohye $\mathrm{T}$. Molecular basis of maternal age-related increase in oocyte aneuploidy.CongenitAnom.2012;52(1):815.doi: 10.1111/ j.1741-4520.2011.00350.x. [PubMed]
[14] Norton ME, Brar H, Weiss J, Karimi A, Laurent LC, Caughey AB, Rodriguez MH, Williams J 3rd, Mitchell ME, Adair $\mathrm{CD}$, Lee H, Jacobsson B, Tomlinson MW, Oepkes D, Hollemon D, Sparks AB, Oliphant A, Song K.Non-Invasive Chromosomal Evaluation (NICE) Study: results of a multicenter prospective cohort study for detection of fetal trisomy 21 and trisomy 18 . Am J Obstet Gynecol. 2012; 207(2):137.e1-8. doi: 10.1016/ j.ajog.2012.05.021. [PubMed]

[15] Van den Berg MM, van Maarle MC, van Wely M, Goddijn M. Genetics of early miscarriage. Biochim Biophys Acta. 2012; 1822 (12): 1951-9.doi:10.1016/j.bbadis.2012.07.001. [PubMed]

[16] Franssen MT, Korevaar JC,van der Veen F, Leschot NJ, Bossuyt PM, Goddijn M. Reproductive outcome after chromosome analysis in couples with two or more miscarriages: index [corrected]-control study. BMJ. 2006; 332(7544):759-63. doi: 10.1136/ bmj.38735.459144.2F. [PubMed]

[17] Franssen MT, Musters AM, van der Veen F, Repping S, Leschot NJ, Bossuyt PM, Goddijn M, Korevaar JC. Reproductive outcome after PGD in couples with recurrent miscarriage carrying a structural chromosome abnormality: a systematic review. Hum Reprod Update. 2011; 17(4):467-75. doi: 10.1093/ humupd/. [PubMed]

[18] Calleja-Agius J, Jauniaux E, Pizzey AR, Muttukrishna S. Investigation of systemic inflammatory response in first trimester pregnancy failure. Hum Reprod. 2012; 27(2):349-57.doi:10.1093/humrep/der402.

[PubMed]

[19] Tang AW, Alfirevic Z, Quenby S. Natural killer cells and pregnancy outcomes in women with recurrent miscarriage and infertility: a systematic review. Hum Reprod. 2011; 26(8):1971-80.doi: $\quad$ 10.1093/humrep/der164. [PubMed]

[20] Nielsen HS, Steffensen R, Varming K, Van Halteren AG, Spierings E, Ryder LP, Goulmy E, Christiansen OB. Association of HYrestricting HLA class II alleles with pregnancy outcome in patients with recurrent miscarriage subsequent to a firstborn boy. Hum Mol Genet. 2009;18(9):1684-91.doi:10.1093/ hmg/ ddp077. [PubMed]

[21] Porter TF, LaCoursiere Y, Scott JR. Immunotherapy for recurrent miscarriage. Cochrane Database Syst Rev. 2006; 2, CD000112.doi:10.1002/14651858. CD000112.pub2. [PubMed]

[22] Ata B, Tan SL, Shehata F, Holzer H, Buckett W. A systematic review of intravenous immunoglobulin for treatment of unexplained 
recurrent miscarriage. Fertil Steril. 2011; 95(3):10805.e12.doi:10.1016/j.fertnstert.2010.1 2.021. [PubMed]

[23] Girardi G, Redecha P, Salmon JE. Heparin prevents antiphospholipid antibody-induced fetal loss by inhibiting complement activation. Nat Med. 2004; 10 (11):1222-1226. doi :10.1038/nm1121. [PubMed]

[24] McNamee K, Dawood F, Farquharson R. Recurrent miscarriage and thrombophilia: An update. Curr Opin Obstet Gynecol. 2012; 24(4):22934.doi:10.1097/GCO.0b013e3283558 5dc. [PubMed]

[25] American College of Obstetricians and Gynecologists Committee on Practice Bulletins-Obstetrics. ACOG Practice Bulletin No.118: Antiphospholipid syndrome. Obstet Gynecol. 2011; 117(1):192-9. doi: 10.1097/ AOG.0b013e31820a61f9. [PubMed]

[26] Miyakis S, Lockshin MD, Atsumi T, Branch DW, Brey RL, Cervera R, Derksen RH, DE Groot PG, Koike T, Meroni PL, Reber G, Shoenfeld Y, Tincani A, Vlachoyiannopoulos PG, Krilis SA. International consensus statement on an update of the classification criteria for definite antiphospholipid syndrome (APS). J Thromb Haemost. 2006; 4(2):295306.doi:10.1111/j.15387836.2006.01753.x. [PubMed]

[27] Rey E, Kahn SR, David M, Shrier I. Thrombophilic disorders and fetal loss: a metaanalysis. Lancet. 2003; 361 (9361):901-8. doi: 10.1016/S0140-6736(03)12771-7. [PubMed]

[28] Kovalevsky G, Gracia CR, Berlin JA, Sammel MD, Barnhart KT. Evaluation of the association between hereditary thrombophilias and recurrent pregnancy loss: a meta-analysis. Arch Intern Med. 2004;164:558-63. doi:10.1001/archinte.164.5.558. [PubMed]

[29] Zetterberg H. Methylenetetrahydrofolate reductase and transcobalamin genetic polymorphisms in human spontaneous abortion: Biological and clinical implications. Reprod Biol Endocrinol. 2004; 2:7. doi: 10.1186/1477-7827-2-7. [PubMed]

[30] Jeve YB, Davies W. Evidence-based management of recurrent miscarriages. J Hum Reprod Sci. 2014;7 (3):159-69. doi: 10.4103/ 0974-1208.142475. [PubMed]

[31] Hong Y, Xie QX, Chen CY, Yang C, Li YZ, Chen DM, Xie MQ. Insulin resistance in firsttrimester pregnant women with pre-pregnant glucose tolerance and history of recurrent spontaneous abortion. J Biol Regul Homeost Agents. 2013; 27 (1):225-31. [PubMed]

[32] Hanson U, Persson B, Thunell S. Relationship between haemoglobin A1C in early type 1 (insulin-dependent) diabetic pregnancy and the occurrence of spontaneous abortion and fetal malformation in Sweden. Diabetologia. 1990;33 (2):100-4. [PubMed]

[33] Malkani S, DeSilva T. Controversies on how diabetes is diagnosed. Curr Opin Endocrinol Diabetes Obes. 2012;19 (2):97-103. doi: 10.1097/MED.0b013e32835168c0. [PubMed]

[34] van den Boogaard E, Vissenberg R, Land JA, van Wely $M$, van der Post JA, Goddijn $M$, Bisschop PH. Significance of (sub) clinical thyroid dysfunction and thyroid autoimmunity before conception and in early pregnancy: a systematic review. Hum Reprod Update. 2011; 17(5):605-19. doi: 10.1093/humupd/dmr024. [PubMed]

[35] Rushworth FH, Backos M, Rai R, Chilcott IT, Baxter N, Regan L. Prospective pregnancy outcome in untreated recurrent miscarriers with thyroid autoantibodies. Hum Reprod 2000;15 (7):1637-9. [PubMed]

[36] Robinson L, Gallos ID, Conner SJ, Rajkhowa M, Miller D, Lewis S, Kirkman-Brown J, Coomarasamy A. The effect of sperm DNA fragmentation on miscarriage rates: a systematic review and meta-analysis. Hum Reprod.2012;27(10):290817.doi:10.1093/humr ep/des261. [PubMed]

[37] Ribas-Maynou J, Garcia-Peiro A, FernandezEncinas A, Amengual MJ, Prada E, Cortes P, Navarro J, Benet J. Double stranded sperm DNA breaks, measured by Comet assay, are associated with unexplained recurrent miscarriage in couples without a female factor. PLoS One. 2012; 7 (9):e44679. doi: 10.1371/ journal.pone.0044679. [PubMed]

[38] Teklenburg G, Salker M, Molokhia M, Lavery $\mathrm{S}$, Trew G, Aojanepong T, Mardon HJ, Lokugamage AU, Rai R, Landles C, Roelen BA, Quenby S, Kuijk EW, Kavelaars A, Heijnen CJ, Regan L, Brosens JJ, Macklon NS. Natural selection of human embryos: decidualizing endometrial stromal cells serve as sensors of embryo quality upon implantation. PLoS One. 2010; 5(4):e10258. doi: 10.1371/ journal.pone.0010258. [PubMed]

[39] Quenby S, Vince G, Farquharson R, Aplin J. Recurrent miscarriage: a defect in nature's quality control? Hum Reprod. 2002; 17 (8):1959-1963. [PubMed]

[40] Salker M, Teklenburg G, Molokhia M, Lavery $\mathrm{S}$, Trew G, Aojanepong T, Mardon HJ, Lokugamage AU, Rai R, Landles C, Roelen BA, Quenby S, Kuijk EW, Kavelaars A, Heijnen CJ, Regan L, Macklon NS, Brosens JJ. Natural selection of human embryos: impaired decidualization of endometrium disables embryo-maternal interactions and causes recurrent pregnancy loss. PLoS One. 2010; 5(4):e10287. doi: 10.1371 /journal. pone.0010287. [PubMed] 
[41] Weimar CH, Kavelaars A, Brosens JJ, Gellersen B, de Vreeden-Elbertse JM, Heijnen CJ, Macklon NS. Endometrial stromal cells of women with recurrent miscarriage fail to discriminate between high- and low-quality human embryos. PLoS One. 2012; 7(7):e41424. doi: 10.1371/journal.pone.0041424. [PubMed]

[42] Chan YY, Jayaprakasan K, Tan A, Thornton JG, Coomarasamy A, Raine-Fenning NJ. Reproductive outcomes in women with congenital uterine anomalies: a systematic review. Ultrasound Obstet Gynecol. 2011; 38(4): 371-82. doi: 10.1002 /uog.10056. [PubMed]

[43] Kowalik CR, Goddijn M, Emanuel MH, Bongers MY, Spinder T, de Kruif JH, Mol BW, Heineman MJ. Metroplasty versus expectant management for women with recurrent miscarriage and a septate uterus. Cochrane Database Syst Rev. 2011; 6, CD008576. doi: 10.1002/14651858. [PubMed]

[44] Olpin JD, Heilbrun M. Imaging of Mullerian duct anomalies. Clin Obstet Gynecol. 2009; 52(1):40-56. doi: 10.1097/GRF.0b013e3181958439. [PubMed]

[45] Reda A, Hamid AS, Mostafa R, Refaei E. Comparison between findings of saline infusion sonohysterography and office hysteroscopy in patients with recurrent implantation failure. $\mathbf{J}$ Hum Reprod Sci. 2016; 9(4):236-240. doi: 10.4103/0974-1208.197661. [PubMed]

[46] Rull K, Christiansen OB, Nagirnaja L, Steffensen R, Margus T, Laan M. A modest but significant effect of CGB5 gene promoter polymorphisms in modulating the risk of recurrent miscarriage. Fertil Steril. 2013; 99(7):1930-6.e6. doi: 10.1016/j.fertnstert.2013.02.019. [PubMed]

[47] Andersen AM, Andersen PK, Olsen J, Gronbaek M, Strandberg-Larsen K. Moderate alcohol intake during pregnancy and risk of fetal death. Int J Epidemiol. 2012; 41(2):40513. doi: 10.1093/ije/dyr189. [PubMed]

[48] Bech BH, Nohr EA, Vaeth M, Henriksen TB, Olsen J. Coffee and fetal death: a cohort study with prospective data. Am J Epidemiol. 2005;162(10):983-90. [PubMed]

[49] Wisborg K, Kesmodel U, Henriksen TB, Hedegaard M, Secher NJ. A prospective study of maternal smoking and spontaneous abortion. Acta Obstet Gynecol Scand. 2003;82(10):93641. [PubMed]

[50] Boots C, Stephenson MD. Does obesity increase the risk of miscarriage in spontaneous conception: a systematic review. Semin Reprod Med. 2011; 29(6):507-13. doi: 10.1055/s-00311293204. [PubMed]
[51] Ugwumadu A, Manyonda I, Reid F, Hay P. Effect of early oral clindamycin on late miscarriage and preterm delivery in asymptomatic women with abnormal vaginal flora and bacterial vaginosis: a randomised controlled trial. Lancet. 2003; 361(9362):983-8. doi:10.1016/S0140-6736(03)12823-1. [PubMed]

[52] Brigham SA, Conlon C, Farquharson RG. A longitudinal study of pregnancy outcome following idiopathic recurrent miscarriage. Hum Reprod. 1999; 14 (11):2868-71. [PubMed]

[53] Liddell HS, Pattison NS, Zanderigo A. Recurrent miscarriage - outcome after supportive care in early pregnancy. Aust N Z J Obstet Gynaecol. 1991; 31 (4):320-2. [PubMed]

[54] Weng X, Odouli R, Li DK. Maternal caffeine consumption during pregnancy and the risk of miscarriage: A prospective cohort study. Am J Obstet Gynecol. 2008; 198(3):279.e1-8. doi: 10.1016/j.ajog.2007.10.803 [PubMed]

[55] Rumbold A, Middleton P, Pan N, Crowther CA. Vitamin supplementation for preventing miscarriage. Cochrane Database Syst Rev. 2011;1:CD004073.doi:10.1002/14651858.CD0 04073.pub3. [PubMed]

[56] Barber JC, Cockwell AE, Grant E, Williams S, Dunn R, Ogilvie CM. Is karyotyping couples experiencing recurrent miscarriage worth the cost? BJOG. 2010; 117 (7):885-8.doi: 10.1111/j.1471-0528.2010.02566.x. [PubMed]

[57] Twisk M, Mastenbroek S, Hoek A, Heineman MJ, van der Veen F, Bossuyt PM, Repping S, Korevaar JC. No beneficial effect of preimplantation genetic screening in women of advanced maternal age with a high risk for embryonic aneuploidy. Hum Reprod. 2008; 23(12):2813-7. doi: 10.1093/humrep/den231. [PubMed]

[58] Ogilvie CM, Braude P, Scriven PN. Successful pregnancy outcomes after preimplantation genetic diagnosis (PGD) for carriers of chromosome translocations. Hum Fertil (Camb). 2001; 4 (3):168-71. [PubMed]

[59] Scriven PN, Flinter FA, Braude PR, Ogilvie CM. Robertsonian translocations - reproductive risks and indications for preimplantation genetic diagnosis. Hum Reprod. 2001; 16 (11):2267-73. [PubMed]

[60] Lalioti MD. Can preimplantation genetic diagnosis overcome recurrent pregnancy failure? Curr Opin Obstet Gynecol. 2008; 20(3):199204.doi:10.1097/GCO.0b013e3282f8 8e0c. [PubMed] 
[61] Garrisi JG, Colls P, Ferry KM, Zheng X, Garrisi MG, Munné S. Effect of infertility, maternal age, and number of previous miscarriages on the outcome of preimplantation genetic diagnosis for idiopathic recurrent pregnancy loss. Fertil Steril. 2009; 92(1):28895.doi:10.1016/j.fertnstert.2008.05.056.[PubMe d]

[62] Brix N, Secher NJ, McCormack CD, Helmig RB, Hein M, Weber T, Mittal S, Kurdi W, Palacio M, Henriksen TB; CERVO group. Randomised trial of cervical cerclage, with and without occlusion, for the prevention of preterm birth in women suspected for cervical insufficiency. BJOG. 2013; 120(5):613-20. doi: 10.1111/1471-0528.12119. [PubMed]

[63] Hume H, Rebarber A, Saltzman DH, Roman AS, Fox NS. Ultrasound-indicated cerclage: Shirodkar vs. McDonald. J Matern Fetal Neonatal Med. 2012; 25(12):2690-2. doi: 10.3109/14767058.2012.716465. [PubMed]

[64] Conde-Agudelo A, Romero R, Nicolaides K, Chaiworapongsa T, O'Brien JM, Cetingoz E, da Fonseca E, Creasy G, Soma-Pillay P, Fusey S, Cam C, Alfirevic Z, Hassan SS. Vaginal progesterone vs. cervical cerclage for the prevention of preterm birth in women with a sonographic short cervix, previous preterm birth, and singleton gestation: A systematic review and indirect comparison metaanalysis. Am J Obstet Gynecol. 2013; 208(1):42.e1. 42. e18.doi: 10.1016/j.ajog.2012.10.877. [PubMed]

[65] Hirahara F, Andoh N, Sawai K, Hirabuki T, Uemura T, Minaguchi H. Hyperprolactinemic recurrent miscarriage and results of randomized bromocriptine treatment trials. Fertil Steril. 1998; 70(2):246-52. [PubMed]

[66] Twig G, Shina A, Amital H, Shoenfeld Y. Pathogenesis of infertility and recurrent pregnancy loss in thyroid autoimmunity. J Autoimmun. 2012; 38(2-3):J275-81. doi: 10.1016/j.jaut.2011.11.014. [PubMed]

[67] Raghupathy R, Al-Mutawa E, Al-Azemi M, Makhseed M, Azizieh F, Szekeres-Bartho J. Progesterone-induced blocking factor (PIBF) modulates cytokine production by lymphocytes from women with recurrent miscarriage or preterm delivery. J Reprod Immunol. 2009; 80(1-2):91-9. doi: 10.1016/j.jri.2009.01.004. [PubMed]

[68] Haas DM, Ramsey PS. Progestogen for preventing miscarriage. Cochrane Database SystRev.2008;2:CD003511.doi:10.1002/14651 858.CD003511.pub2. [PubMed]

[69] Carrington B, Sacks G, Regan L. Recurrent miscarriage: Pathophysiology and outcome. Curr Opin Obstet Gynecol. 2005; 17(6):591-7. [PubMed]
[70] Palomba S, Falbo A, Orio F Jr, Zullo F. Effect of preconceptional metformin on abortion risk in polycystic ovary syndrome: a systematic review and meta-analysis of randomized controlled trials. Fertil Steril. 2009; 92(5):164658.doi:10.1016/j.fertnstert.2008.08.087.

[PubMed]

[71] Ziakas PD, Pavlou M, Voulgarelis M. Heparin treatment in antiphospholipid syndrome with recurrent pregnancy loss: A systematic review and meta-analysis. Obstet Gynecol. 2010; 115(6):125662.doi:10.1097/AOG.0b013e3181d eba40. [PubMed]

[72] Empson M, Lassere M, Craig J, Scott J. Prevention of recurrent miscarriage for women with antiphospholipid antibody or lupus anticoagulant. Cochrane Database Syst Rev. 2005;(2):CD002859.doi:10.1002/14651858.CD 002859.pub2. [PubMed]

[73] Dendrinos S, Sakkas E, Makrakis E. Lowmolecular-weight heparin versus intravenous immunoglobulin for recurrent abortion associated with antiphospholipid antibody syndrome. Int J Gynaecol Obstet. 2009;104 (3):223-5.doi: $\quad$ 10.1016/j.ijgo.2008.11.010. [PubMed]

[74] Gris JC, Mercier E, Quéré I, Lavigne-Lissalde G, Cochery-Nouvellon E, Hoffet M, RipartNeveu S, Tailland ML, Dauzat M, Marès P. Low-molecular weight heparin versus low-dose aspirin in women with one fetal loss and constitutional thrombophilic disorder. Blood. 2004; 103:3695-9. Doi :10.1182/blood-200312-4250. [PubMed]

[75] Shimada S, Takeda M, Nishihira J, Kaneuchi M, Sakuragi N, Minakami H, Yamada H. A high dose of intravenous immunoglobulin increases CD94 expression on natural killer cells in women with recurrent spontaneous abortion. Am J Reprod Immunol. 2009; 62(5):301-7. doi: 10.1111/j.1600-0897. 2009. 00739.x. [PubMed]

[76] Shreeve N, Sadek K. Intralipid therapy for recurrent implantation failure: New hope or false dawn? J Reprod Immunol. 2012;93(1):3840. doi: 10.1016/j.jri.2011.11.003. [PubMed]

[77] Hutton B, Sharma R, Fergusson D, Tinmouth A, Hebert P, Jamieson J, Walker M. Use of intravenous immunoglobulin for treatment of recurrent miscarriage: A systematic review. BJOG.2007;114(2):134-42.doi:10.1111/j.14710528.2006.01201.x. [PubMed]

[78] Stephenson MD, Kutteh WH, Purkiss S, Librach C, Schultz P, Houlihan E, Liao C. Intravenous immunoglobulin and idiopathic secondary recurrent miscarriage: a multi 
centered randomized placebo-controlled trial. Hum Reprod. 2010; 25:2203-9. doi: 10.1093/ humrep/deq179. [PubMed]

[79] Kaandorp SP, Goddijn M, van der Post JA, Hutten BA, Verhoeve HR, Hamulyák K, Mol BW, Folkeringa N, Nahuis M, Papatsonis DN, Büller HR, van der Veen F, Middeldorp S. Aspirin plus heparin or aspirin alone in women with recurrent miscarriage. $\mathrm{N}$ Engl $\mathrm{J}$ Med. 2010; 362(17): 158696. doi:10.1056/ NEJMoa1000641. [PubMed]

[80] Coomarasamy A, Truchanowicz EG, Rai R. Does first trimester progesterone prophylaxis increase the live birth rate in women with unexplained recurrent miscarriages? BMJ. 2011; 342:d1914. doi: 10.1136/bmj.d1914. [PubMed]
[81] Morley LC, Simpson N, Tang T. Human chorionic gonadotrophin (hCG) for preventing miscarriage.CochraneDatabaseSystRev.2013;1: CD008611.doi:10.1002/14651858.CD008611.p ub2. [PubMed]

[82] Harrison RF. Human chorionic gonadotrophin (hCG) in the management of recurrent abortion; results of a multi-centre placebo-controlled study. Eur J Obstet Gynecol Reprod Biol. 1992; 47:175-9. [PubMed]

[83] Lash GE, Bulmer JN. Do uterine natural killer (uNK) cells contribute to female reproductive disorders? J Reprod Immunol. 2011; 88(2):156-64. doi: 10.1016/j.jri.2011.01.003. [PubMed]

Citation: Ibrahim A. Abdelazim, Mohannad AbuFaza, Prashant Purohit, Rania H. Farag, Miscarriage Definitions, Causes and Management: Review of Literature. ARC Journal of Gynecology and Obstetrics 2017; 2(3):20-31. DOI: dx.doi.org/10.20431/2455-9792.0203005

Copyright: (c) 2017 Authors. This is an open-access article distributed under the terms of the Creative Commons Attribution License, which permits unrestricted use, distribution, and reproduction in any medium, provided the original author and source are credited. 